\title{
Morphometric differences in the grasshopper Cornops aquaticum (Bruner, 1906) from South America and South Africa
}

Accepted March 19, 2008

Joachim Adis, Carlos F. Sperber, Edward G. Brede, Soledad Capello, Maria Celeste Franceschinl,

Martin Hill, Marcos G. Lhano, Marinêz M. Marques, Ana L. Nunes, Perry Polar

(JA,EGB)Tropical Ecology Working Group, Max-Planck-Institute for Limnology, Postfach 165, 24302 Plön, Germany. Email: adis@mpilploen.mpg.de and brede@mpil-ploen.mpg.de (Prof. Dr. Joachim Adis, deceased August 29, 2007)

(CFS) Laboratório de Orthopterologia, Departamento de Biologia Geral, Universidade Federal de Viçosa, 36570-000 Viçosa-MG, Brazil. Email: sperber@ufv.br

(SC)Instituto Nacional de Limnología (INALI-CONICET-UNL), José Maciá 1933, 3016 Santo Tomé, Santa Fé, Argentina. Email: solecapello1@ yahoo.com.ar

(MCF)Centro de Ecologia Aplicada del Litoral (CECOAL-CONICET), Ruta Prov. 5, km 2,5 - cc 291, 3400 Corrientes, Argentina. Email: celestefranceschini@yahoo.com.ar

(MH)Department of Zoology and Entomology, Rhodes University, P.O. Box 94, Grahamstown, 6140, South Africa. Email: m.p.hill@ru.ac.za (MGL)PRODOC, Laboratório de Orthopterologia, Departamento de Biologia Geral, Universidade Federal de Viçosa, $36570-000$ ViçosaMG, Brazil. E-mail: entomology@gmail.com

(MMM) Instituto de Biociências (Departamento de Biologia e Zoologia), Universidade Federal de Mato Grosso, Avenida Fernando Corrêa da Costa s/n, 78060-900 Cuiabá-MT, Brazil. Email: marinez@ufmt.br

(ALN)Muséu Paraense Emilio Goeldi, Caixa Postal 399, 66040-970 Belém-PA, Brazil. Email: alnunes@museu-goeldi.br (PP)CAB International, Gordon Street, Curepe, Trinidad. Email: p.polar@cabi.org

\begin{abstract}
The semi-aquatic grasshopper Cornops aquaticum is native to South America and inhabits lowlands from southern Mexico to Central Argentina and Uruguay. It is host-specific to aquatic plants in the genera Eichhornia and Pontederia. A quarantine population has existed in South Africa for $10 \mathrm{y}$, and it is planned to release it there as a biological control agent of water hyacinth, E. crassipes. Various studies of C. aquaticum are coordinated under HICWA (www.mpil-ploen.mpg.de). This paper compares the morphometry of the release population and 11 native populations in South America. We tested four hypotheses: 1) South African and South American populations of $C$. aquaticum differ in morphology; 2) the South African laboratory population is more similar to other isolated populations in South America than to nonisolated populations; 3) morphology differs across sites; 4) morphology differs with host plant. South African populations differed from continental nonisolated populations, but not from continental isolated ones. Isolated populations presented smaller individuals than nonisolated, but there was also a change in male morphology: while in nonisolated populations male wing length was similar to their body length, in isolated populations, male wings were smaller than body length. Females were larger when on Eicchornia azurea than on E. crassipes, while males presented larger wings than their body on E. azurea, and similar lengths on E. crassipes. These morphological changes may have resulted from phenotypic plasticity, selection for small size, or because of a loss of genetic diversity in quantitative traits.
\end{abstract}

\section{Key words}

geography, isolation, morphology, morphometrics, body size, wing, Eichhornia, Pontederia, water hyacinth, Neotropics

\section{Introduction}

The semi-aquatic grasshopper Cornops aquaticum (Bruner, 1906 ) is native to South America and inhabits lowlands from southern Mexico to Central Argentina and Uruguay (Adis et al. 2007). It is host- specific to aquatic plants in the genera Eichhornia and Pontederia (Adis \& Junk 2003, Adis \& Victoria 2001); however, different populations generally only have access to either E. azurea or E. crassipes (Silveira-Guido \& Perkins 1975, Lhano et al. 2005, Ferreira
\& Vasconcelos-Neto 2001). Between 1996 and 1997, grasshoppers were collected from various South American sites and established in a quarantine laboratory in Pretoria, South Africa (Oberholzer \& Hill 2001), for eventual release in South Africa as a biological control agent of water hyacinth, E. crassipes (Oberholzer \& Hill 2001). Coevolution of the grasshopper and its host plant (Adis et al. 2004, Brede \& Beebee 2005) is presently studied under the HICWA Project (Host-Insect Coevolution on Water Hyacinth), involving 10 countries (Argentina, Brazil, Colombia, France, Germany, Nicaragua, South Africa, Trinidad, United Kingdom and Uruguay), under the auspices of the Tropical Ecology Working Group of the Max Planck Institute for Limnology at Plön, Germany (www.mpil-ploen.mpg.de).

During our studies, we observed that body size in C. aquaticum appeared to vary with geography and host plant. In addition, we noticed that individuals in our laboratory colony appeared to have become increasingly smaller during $10 \mathrm{y}$ in quarantine. Perhaps simple isolation stimulated this change in body size. If this were true, then we would expect the South African population to be more similar to other isolated populations than to nonisolated ones in South America. In this contribution, morphometric data obtained from 11 wild populations in South America and one 10y-old laboratory population in South Africa are used to test the following hypotheses:

1. South African and South American populations of C. aquaticum differ in morphology.

2.The South African population is more similar to other isolated populations from South America than to nonisolated populations.

3. Morphology differs with geography.

4. Morphology differs with host plant (E. azurea vs E. crassipes).

\section{Materials and methods}

We collected 480 C. aquaticum from 11 sites in South America (see Table 1). The South African quarantine population at Pretoria represents a mixed population derived from Brazil, Mexico, Trini- 
Table 1a. Mean size ( $\mathrm{mm}$ ) of C. aquaticum from populations feeding on E. crassipes in South America and South Africa.

\begin{tabular}{|c|c|c|c|c|c|c|c|c|c|c|c|c|}
\hline \multirow[t]{2}{*}{ Country } & \multirow[t]{2}{*}{ Locality } & \multirow[t]{2}{*}{ Site } & \multirow[t]{2}{*}{ Coordinates } & \multirow[t]{2}{*}{ Sample } & \multicolumn{2}{|c|}{ Number (n) } & \multicolumn{2}{|c|}{ Total length $[\mathrm{A}]$} & \multicolumn{2}{|c|}{ Body length [B] } & \multicolumn{2}{|c|}{ Wing length [I] } \\
\hline & & & & & males & females & males & females & males & females & males & females \\
\hline Argentina & Santa Fe & Rio Catarata & $\begin{array}{l}31^{\circ} 42^{\prime} \mathrm{S} \\
60^{\circ} 45^{\prime} \mathrm{W}\end{array}$ & B & 11 & 18 & $26.6(1.01)$ & $32.3(1.22)$ & $20.1(1.09)$ & $28.2(1.66)$ & $20.5(0.89)$ & $25.0(1.04)$ \\
\hline Brazil & Belém & City & $\begin{array}{l}15^{\circ} 26^{\prime} \mathrm{S} \\
55^{\circ} 47^{\prime} \mathrm{W}\end{array}$ & Q & 40 & 40 & $24.1(1.33)$ & $30.0(1.70)$ & $19.9(0.81)$ & $26.4(1.65)$ & $18.0(1.12)$ & $22.6(1.28)$ \\
\hline Brazil & Manaus & $\begin{array}{l}\text { Ilha de } \\
\text { Marchantaria }\end{array}$ & $\begin{array}{l}03^{\circ} 14^{\prime} \mathrm{S} \\
59^{\circ} 57^{\prime} \mathrm{W}\end{array}$ & $\mathrm{LM}$ & 20 & 26 & $26.5(1.06)$ & $30.6(1.72)$ & $20.9(1.06)$ & $27.3(2.34)$ & $19.9(0.78)$ & $22.7(1.44)$ \\
\hline Brazil & Pantanal & $\begin{array}{l}\text { Fazenda } \\
\text { Ipiranga }\end{array}$ & $\begin{array}{l}16^{\circ} 24^{\prime} \mathrm{S} \\
56^{\circ} 37^{\prime} \mathrm{W}\end{array}$ & GH & 31 & 17 & $25.8(0.94)$ & $31.9(1.77)$ & $20.4(0.86)$ & $27.9(1.29)$ & $19.6(0.80)$ & 24.1 (1.59) \\
\hline Uruguay & Piriapolis & $\begin{array}{l}\text { Laguna del } \\
\text { Sauce }\end{array}$ & $\begin{array}{l}34^{\circ} 50^{\prime} \mathrm{S} \\
55^{\circ} 09^{\prime} \mathrm{W}\end{array}$ & $\mathrm{F}$ & 11 & 8 & $27.3(1.57)$ & $33.0(2.18)$ & $20.6(1.07)$ & $28.0(1.50)$ & $20.8(1.15)$ & $25.2(2.84)$ \\
\hline
\end{tabular}

[ ] = measurements made per Carbonell (2001); ( ) = SD; [Brazil - Belém, S. Africa - Pretoria, Trinidad - Kernahan] = isolated populations.

Table 1b. Mean size (mm) of C. aquaticum from populations feeding on E. azurea in South America.

\begin{tabular}{|c|c|c|c|c|c|c|c|c|c|c|c|c|}
\hline \multirow[t]{2}{*}{ Country } & \multirow[t]{2}{*}{ Locality } & \multirow[t]{2}{*}{ Site } & \multirow[t]{2}{*}{ Coordinates } & \multirow[t]{2}{*}{ Sample } & \multicolumn{2}{|c|}{ Number (n) } & \multicolumn{2}{|c|}{ Total length [A] } & \multicolumn{2}{|c|}{ Body length [B] } & \multicolumn{2}{|c|}{ Wing length [I] } \\
\hline & & & & & males & females & males & females & males & females & males & females \\
\hline Argentina & Corrientes & $\begin{array}{l}\text { Rio } \\
\text { Paraná }\end{array}$ & $\begin{array}{l}27^{\circ} 29^{\prime} \mathrm{S} \\
58^{\circ} 53^{\prime} \mathrm{W}\end{array}$ & $\mathrm{xM}$ & 32 & 9 & $28.1(1.24)$ & $33.0(3.04)$ & $20.4(1.06)$ & $30.2(1.50)$ & $22.0(1.02)$ & $26.3(1.22)$ \\
\hline
\end{tabular}

[ ] = measurements made per Carbonell (2001); ( ) = SD

dad and Venezuela (Hill \& Oberholzer 2000). Populations from an agriculturally disturbed site in Trinidad, from within the city of Belém, and from S. Africa, represent geographically "isolated" populations ( $c f$. Fig. 1). Total length, body length and wing length (as defined by Carbonell 2001) of adults (both sexes) were used as morphometric characters for data analysis (Fig. 2). The length of the hind femur, a valid character to define nymphal stages in $C$. aquaticum (Franceschini et al. 2005), was omitted, as adult specimens easily lose their hind legs when preserved in $\geq 70 \%$ ethanol.

\section{Statistical analysis}

To test Hypotheses 1, 3, and 4, we used univariate mixed-effects models (Crawley 2002a,b) to test statistically if morphology varied with geography and host plant (Manly 2000). We considered 'grasshopper individual' nested within 'sample' as random effects (Crawley 2002a) to avoid pseudoreplication (grasshopper individual) (Hurlbert 1984, Crawley 2002a), and to allow evaluation of the importance of variation among sampled sites (grasshopper populations) on morphometry (Buckley et al. 2003, Pinheiro \& Bates 2000). Length was used as the response variable, while the corresponding morphological character (wing $v$ s body length) was considered one of the explanatory factors, with two levels. Because total length included wing length (Fig. 2), these two measurements were statistically correlated. Therefore, we used only body length and wing length in the analyses, disregarding total length. Initially we adjusted a maximal model, and simplified it subsequently by deleting nonsignificant effects (Crawley 2002a). The fixed effects of the maximal tested model used to test Hypotheses 1 and 3, included gender, geography, morphological character (whether wing or body length) and their interaction terms. We used the interaction terms to test whether morphological characters responded differently to geography and gender. Geography was entered as a categorical variable with three levels: 'nonisolated', 'South Africa' and 'other isolated populations'.

To test hypotheses that the isolated S. African laboratory population is similar to other isolated, wild populations, but differs from nonisolated ones, we performed contrast analyses, pooling the geographical levels 'South Africa' with 'other isolated populations'. The use of contrasts instead of a posteriori comparisons allowed us to test explicit hypotheses with biological explanations.

We tested for the effect of random variation among grasshopper populations by deleting the random effect 'sample' from the minimal adequate model and noting the change in the log of the maximized restricted likelihood, as per Fox (2002). Significance of fixed effects was tested by deleting each explanatory variable from the model and noting the change in maximum likelihood (Crawley 2002a). Significance tests of fixed effects within the minimal model were shown as F-tests.

We tested the hypothesis that the variance of the isolated South African population is smaller than that of the nonisolated populations by using Fisher's F-test for each measured morphological character. We also tested the hypothesis that there are differences in grasshopper morphometry between host plants, by adjusting mixedeffects models with host plant, morphological character and their interaction terms as fixed effects. Because C. aquaticum grasshopper 
populations collected on E. azurea were all nonisolated, we compared them exclusively with other nonisolated populations using a subset of all available data $(\mathrm{n}=319)$. All analyses were performed at a $5 \%$ significance level and assumed normal error distribution, (Fowler \& Cohen 1996); they were performed with the statistical package R (R Development Core Team 2006).

\section{Results}

1. The inclusion of the sample site from which the grasshoppers were drawn as a random effect, increased significantly the amount of variation explained by the model (likelihood ratio $=86.58, \mathrm{p}<$ $0.0001)$. This shows that there was random variation among grasshopper populations associated with a significant covariance within sites, i.e., there were morphological differences among populations (Fig. 3), which must be considered in the mixed-effects model.

2. The pooling of the levels 'South Africa' with 'other isolated populations' did not reduce the variation explained by the fitted statistical model (likelihood ratio $=3.71, \mathrm{p}=0.45$ ). This shows that there was no difference in the response between the geographical groups 'South Africa' and 'other isolated populations'. This allowed these two groups to be merged together as a third (named 'isolated populations').

3. The minimal adequate model (Table 2) presented highest order interactions of morphological characters with sex and geography. Wing length and body length did not respond in the same manner (Fig. 4). Females were always larger than males and always presented longer bodies than wings (Table 1, Fig. 4).

4. Both sexes were larger in nonisolated than in isolated populations (Fig. 4), but male and female morphology responded differently to geography. Females maintained similar morphological proportions in all populations, whereas males in isolated populations were not only smaller overall, but had smaller wing-to-body ratios (Fig. 4: Micropterous males).

5. The variance of morphological characters in the isolated S. African population did not differ from nonisolated populations (Table 3).

6. In the host-plant analyses, all interactions (morphological character, sex, and host plant) were significant (Table 4). Females that were collected on E. azurea were larger than those on E. crassipes (Fig. 5). In males, host plant influenced wing length, but not body length.

All four hypotheses are valid: morphology varies geographically, with degree of isolation, and with host plant. South African and South

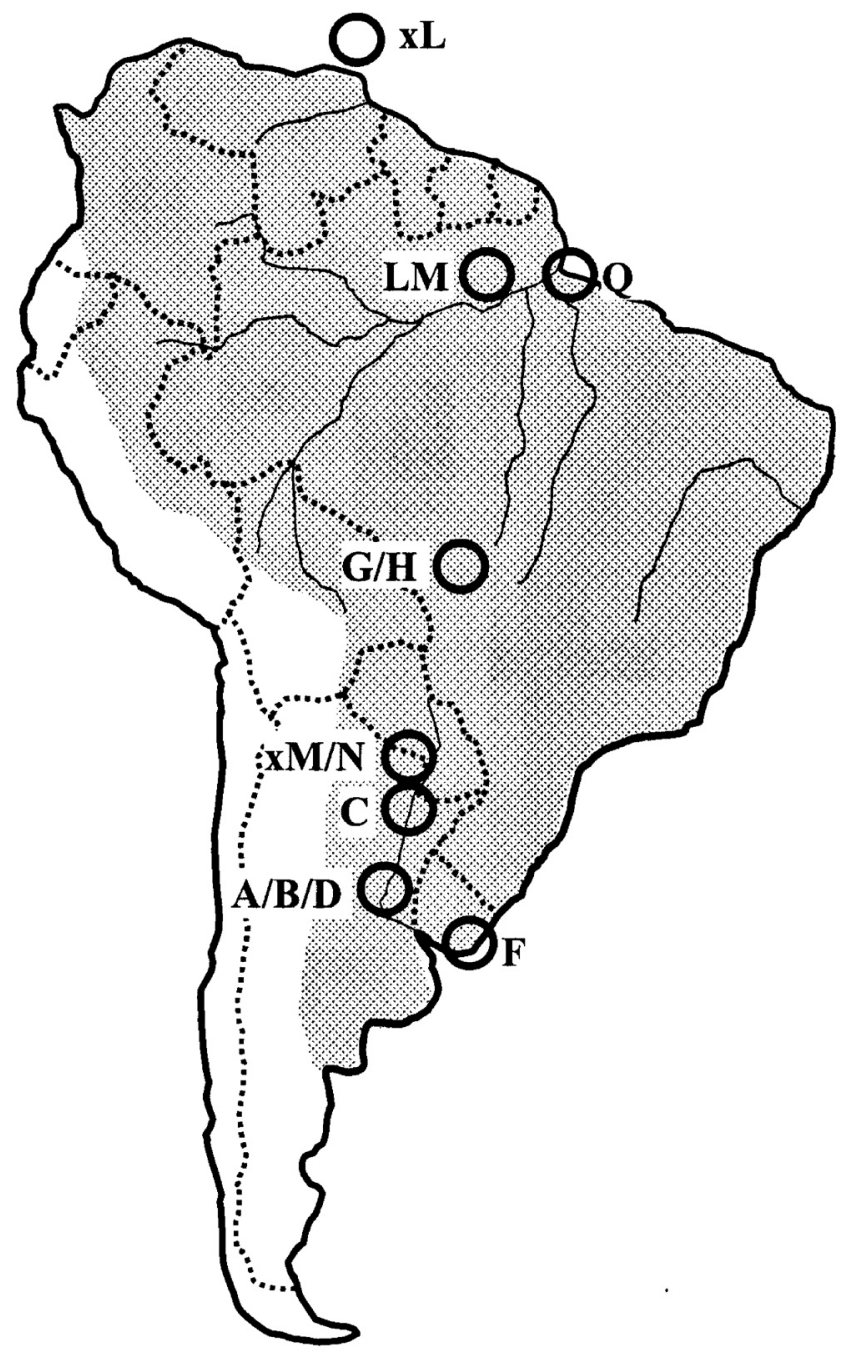

Fig. 1. Sampling locations and reference of C. aquaticum populations in South America. For location of populations see Table 1a/b. Shaded area indicates range of C. aquaticum in South America (according to Adis et al. 2007).

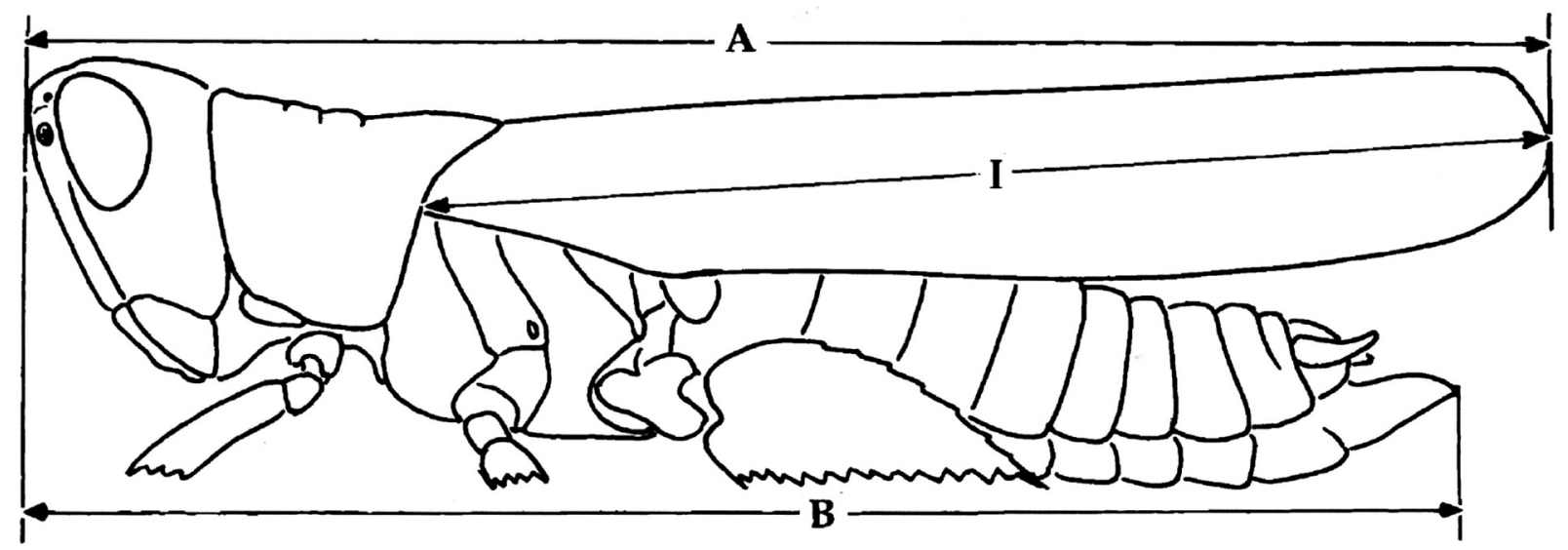

Fig. 2. Morphometric measurements on the grasshoppers, following Carbonell (2001). A: total length, I: wing length, B: body length (only undamaged specimens measured). 


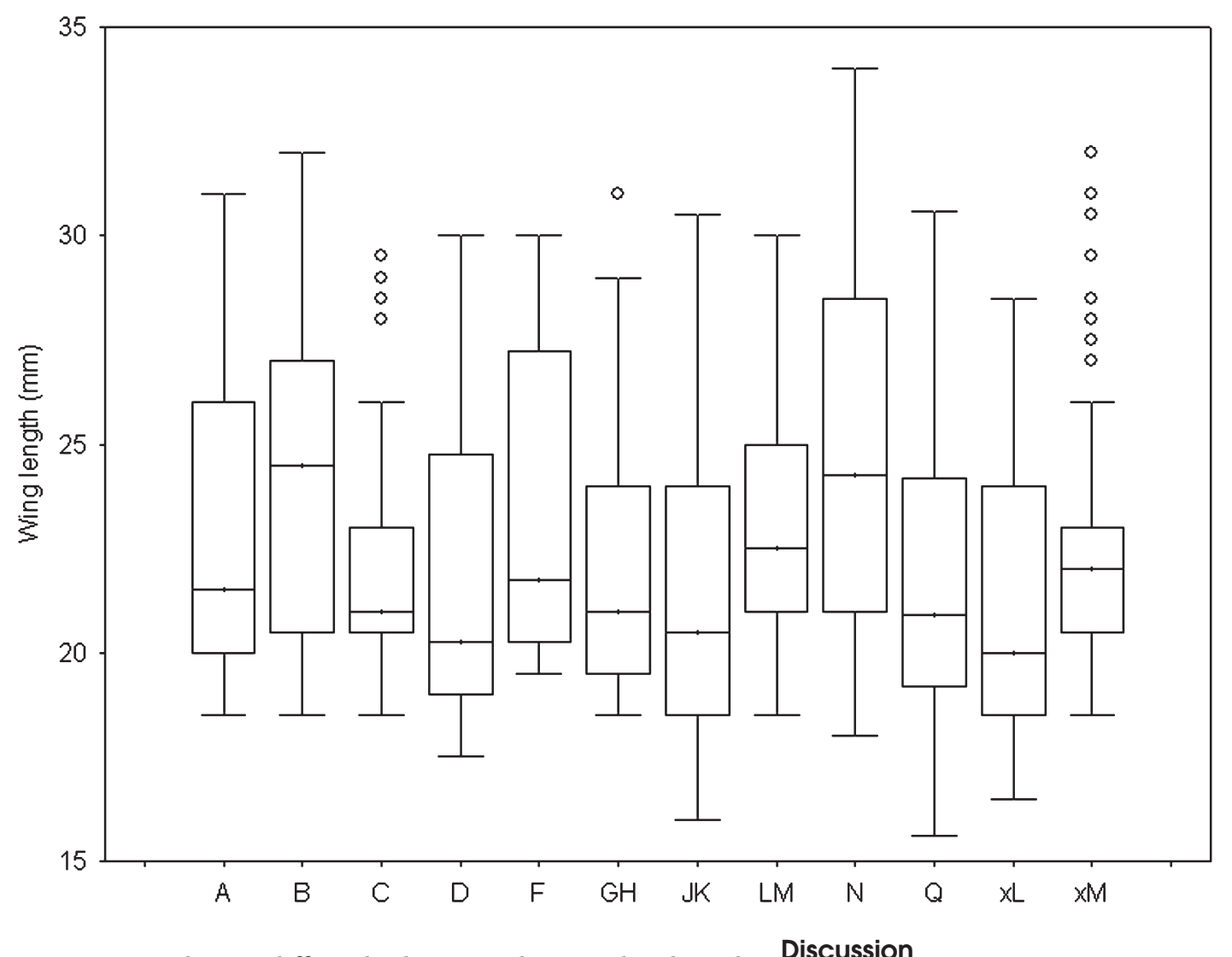

Fig. 3. Wing length (mm) of C. aquaticum among populations. "JK", "Q" and " $\mathrm{xL}$ " represent the isolated populations, "N" and " $\mathrm{xM}$ " the populations collected on $E$. azurea. All other populations were exclusively collected on E. crassipes. For location of samples see Table 1.

American populations differ in body size, with nonisolated South American grasshoppers being larger than the isolated populations (including the South African laboratory population). In addition, females maintain their morphological proportions irrespective of geographical situation and host plant, with those feeding on $E$. azurea being larger than those feeding on E. crassipes. In contrast, males alter the proportion of body to wing lengths according to geography and host plant. In isolated populations, male $C$. aquaticum change their morphology, with a greater proportional reduction in wing length in regard to their body size. Where males feed on E. azurea they present larger wings compared to those on E. crassipes, without altering their body length.

Table 2. Analysis of variance of the adjusted minimal mixed-effects model to explain length $(\mathrm{mm})$ of C. aquaticum grasshoppers. Random effects were individuals $(n=480)$, nested within populations $(\mathrm{n}=12)$. The factor Geography included nonisolated $v$ s isolated populations; the South African population did not differ from the remaining isolated populations.

\begin{tabular}{lccrc}
\hline Source & numDF & denDF & \multicolumn{1}{c}{$\mathrm{F}$} & $\mathrm{P}$ \\
\hline Intercept & 1 & 476 & 11577.76 & $<.0001$ \\
Morphological Character & 1 & 476 & 601.73 & $<.0001$ \\
Sex & 1 & 466 & 2592.83 & $<.0001$ \\
Geography & 1 & 10 & 16.73 & 0.002 \\
Morphol: Sex & 1 & 476 & 638.74 & $<.0001$ \\
Morphol: Geog & 1 & 476 & 18.11 & 0.0001 \\
Sex: Geog & 1 & 466 & 1.56 & 0.21 \\
Morphol: Sex: Geog & 1 & 476 & 15.12 & 0.0001 \\
\hline
\end{tabular}

Fixed effects: Morphological character + Geography + Sex + Interaction terms. Random effects: individual grasshopper, nested within grasshopper population. Number of individual grasshoppers $=480$, number of grasshopper populations $=12$. numDF is numerator degrees of freedom; denDF is denominator degrees of freedom.

\section{Discussion}

In C. aquaticum, morphology varies with geography and host plant. This variation may be determined genetically or environmentally. The smaller overall size of C. aquaticum individuals in isolated populations may have resulted from selection for smaller size or due to a loss of genetic diversity in quantitative traits. A selective pressure for size reduction might be isolation per se, which can reduce the probability of far-dispersing individuals encountering mates, and hence, lower fitness for large individuals which might disperse further. This hypothesis is supported by the fact that island insects are often flightless and small (Diamond 1981, Roff 1994). Denno et al. (2002) tested a similar hypothesis but found no evidence that the low incidence of female macroptery in island populations of the delphicid planthopper Toya venilia was attributable to the effect of isolation.

Various hypotheses compete to explain the apparent reduction in body size of our South African laboratory colony. These include founder effect, inbreeding depression, outbreeding depression promoted by the heterogeneous composition of paternal lineages (Gerloff \& Schmidt-Hempel 2005, Schaal \& Leverich 2005), and selec-

Table 3. Results of independent Fisher's F-tests, comparing the variances of morphological characters between nonisolated South American and isolated South African grasshoppers.

\begin{tabular}{|c|c|c|c|c|c|}
\hline Variable & $\mathrm{F}$ & $\mathrm{N}$ numerator & $\mathrm{N}$ denominator & critical F & $\mathrm{P}$ \\
\hline$q$ total & 1.49 & 135 & 19 & 1.92 & $>0.05$ \\
\hline$\delta$ total & 1.32 & 179 & 18 & 7.95 & $>0.05$ \\
\hline ㅇ body & 1.55 & 19 & 135 & 1.66 & $>0.05$ \\
\hline o body & 1.63 & 18 & 179 & 1.66 & $>0.05$ \\
\hline q wing & 1.52 & 135 & 19 & 1.92 & $>0.05$ \\
\hline s wing & 1.80 & 179 & 18 & 1.95 & $>0.05$ \\
\hline
\end{tabular}


Table 4. Analysis of variance of the adjusted minimal mixedeffects model to evaluate if there were differences in C. aquaticum grasshoppers' morphology between the host plants E. azurea and E. crassipes.

\begin{tabular}{lccrc}
\hline Fixed-effect & numDF & denDF & F-value & P-value \\
\hline Intercept & 1 & 312 & 16230.87 & $<.0001$ \\
Host plant & 1 & 7 & 5.32 & 0.054 \\
Morphological Character & 1 & 312 & 262.39 & $<.0001$ \\
Sex & 1 & 312 & 1834.90 & $<.0001$ \\
Plant: Character & 1 & 312 & 43.14 & $<.0001$ \\
Plant: Sex & 1 & 312 & 22.68 & $<.0001$ \\
Character: Sex & 1 & 312 & 447.23 & $<.0001$ \\
Plant:Character: Sex & 1 & 312 & 16.77 & 0.0001 \\
\hline
\end{tabular}

Fixed effects: Morphological character + host plant + sex + interaction terms. Random effects: individual grasshopper, nested within grasshopper population. Number of individual grasshoppers $=319$, number of grasshopper populations $=9$. numDF is numerator degrees of freedom; denDF is denominator degrees of freedom.

tion for small size. Continuous laboratory breeding may select for small, fast-breeding genotypes that can produce more generations per unit time than larger individuals. Isolation per se may also have influenced body size (Peer \& Taborskyi 2005). Populations that are isolated for several generations may have lost genes for larger size because of inbreeding depression (Futuyma 1986, Eldrige et al. 2004) or genetic drift (Futuyma 1986, Escobar et al. 2005).

In contrast, our results might be explained by phenotypic plasticity. In some locusts, morphology is plastic and determined by population density (phase transformation) (Uvarov 1966, Sword \& Simpson 2000, Simpson et al. 2001, Babah \& Sword 2004). In this study, however, there is no straightforward relationship between population density and isolation. Isolated populations might be spatially constrained and densely packed, as could be the case for the Belém city C. aquaticum population, but could also have plenty of empty surrounding habitat, as in the low-density South African laboratory population, which has been maintained at a population size of $\sim 100$ individuals.

Our results indicate that geography and host plant influence body size more in males than in females. The smaller flexibility in female morphology may reflect developmental-reproductive constraints. Females may increase their individual fitness through a positive correlation between fecundity and body size (but see Barker et al. 2005). However, if a female has a minimum size requirement for successful production of oocytes, this could result in a lower level of resource being available for development of other morphological characters. Alternative explanations for differences in male-female morphological response might be differential linkage of certain genes influencing morphology, or the need for males to invest in large wings if they are the dispersing sex. Finally, adult size is frequently associated with nymphal developmental conditions, whereby wellfed larvae produce larger adults (Price 1997). If nymphal conditions are involved in the observed responses, this may mean that isolation, geography, and poor quality of host plants (i.e., E. crassipes) might be responsible for less favorable conditions.

\section{Conclusions}

1. Morphology of C. aquaticum varies with sex, geography, host plant, and isolation.

2. Sex interacts with geography and with host plant to influence body size.

3. The smaller wings in isolated populations are in accordance with observations in other organisms. Several taxa have lost their

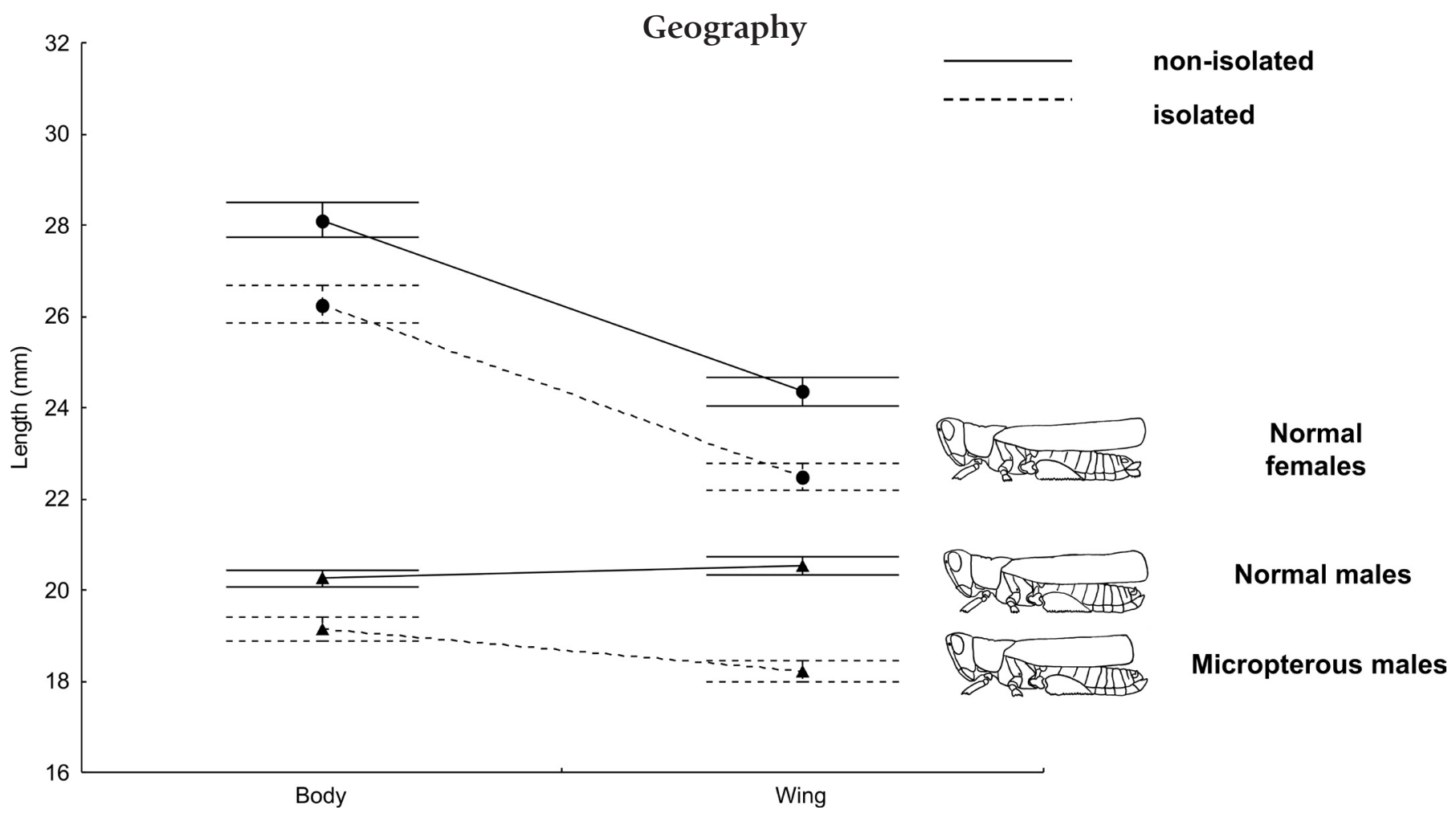

Fig. 4. Average C. aquaticum dimensions with 95\% confidence interval bars, showing the interactions of morphology, sex and geography. Continuous lines: nonisolated populations; dashed lines: isolated populations. All interactions significant ( $\mathrm{p}<0.05)$, as in Table 2. 


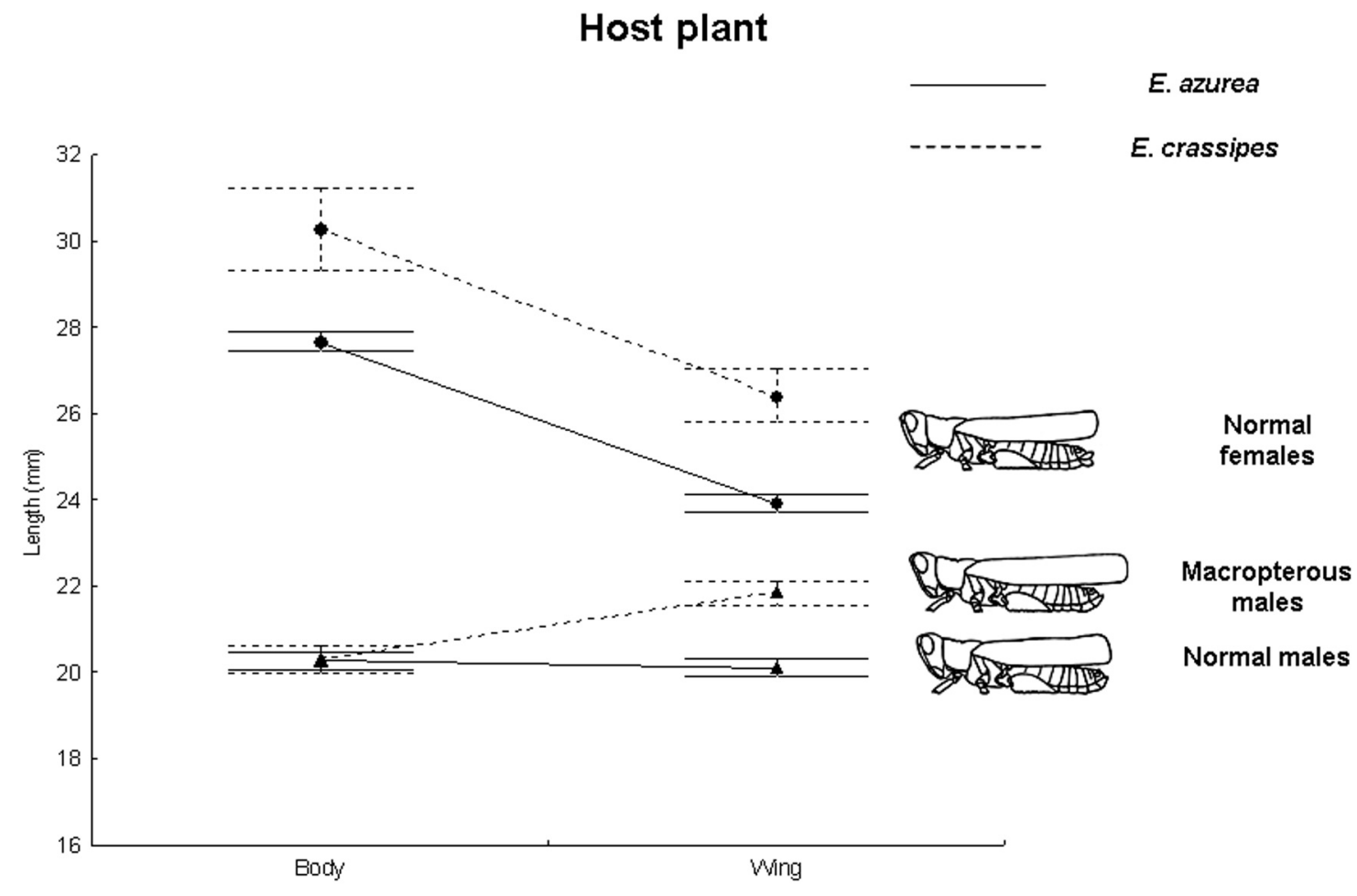

Fig. 5. Average $\pm 95 \%$ confidence interval of $C$. aquaticum grasshopper lengths $(\mathrm{mm})$ from nonisolated populations, comparing two host plants: E. azurea (dashed lines) and E. crassipes (continuous lines). All interactions were significant (Table 4).

wings on islands compared to their continental sister groups (Diamond 1981, Roff 1994).

4. Body size in our C. aquaticum laboratory colony is smaller than that in the wild S. American source populations.

\section{Acknowledgements}

Thanks to E. Drago, M. Marchese(INALI, Santo Tomé/Argentina), A. Poi de Neiff, J.J. Neiff(CECOAL-CONICET, Corrientes/Argentina), H. Oberholzer (ACU, Pretoria/South Africa), and M. Kairo (CABI, Trinidad) for specimen acquisition, and R. Wagner (AG Limnologische Fluss-Station, Max-Planck-Institute for Limnology, Schlitz/ Germany) for manuscript review. MGL and CFS thank CAPES and CNPq for financial support.

\section{References}

Adis J., BustorfE., Lhano M.G., Amedegnato C., Nunes A.L. 2007. Distribution of Cornops grasshoppers (Leptysminae: Acrididae: Orthoptera) in Latin America and the Caribbean Islands. Studies on Neotropical Fauna and Environment 42: 11-24.

Adis J., Junk W.J. 2003. Feeding impact and bionomics of the grasshopper Cornops aquaticum on the water hyacinth Eichhornia crassipes in Central Amazonian floodplains. Studies on Neotropical Fauna and Environment 38: 245-249

Adis J., Victoria R.L. 2001. C3 or C4 macrophytes: a specific carbon source for the development of semi-aquatic and terrestrial arthropods in Central Amazonian river-floodplains to $\mathrm{d}^{13} \mathrm{C}$ values. Isotopes Environmental Health Studies 37: 193-198.

Adis J., Lhano M., Hill M., Junk W.J., Marques M.I., Oberholzer H. 2004. What determines the number of juvenile instars in the tropical grasshopper Cornops aquaticum (Leptysminae: Acrididae: Orthoptera)? Studies on Neotropical Fauna and Environment 39: 127-132.
Babah M.A.O., Sword G.A. 2004. Linking locust gregarization to local resource distribution patterns across a large spatial scale. Environmental Entomology 33: 1577-1583.

Barker M.S., Demuth J.P., Wade M.J. 2005. Maternal expression relaxes constraint on innovation of the anterior determinant, bicoid. PloS Genetics 1: 527-530.

Brede E.G., Beebee T.J.C. 2005. Polymerase chain reaction primers for microsatellite loci in the semi-aquatic grasshopper, Cornops aquaticum. Molecular Ecology Notes 5: 914-916.

Buckley Y.M., Briese D.T., Rees M. 2003. Demography and management of the invasive plant species Hypericum perforatum. I. Using multi-level mixed-effects models for characterizing growth, survival and fecundity in a long-term data set. Journal of Applied Ecology 40: 1481-493.

Carbonell C.S. 2001. The grasshopper tribe Phaeoparini (Acridoidea: Romaleidae). Publications on Orthopteran diversity. The Orthopterists' Society: 1-148.

Crawley M.J. 2002a. Statistical Computing: an Introduction to Data Analysis Using S-plus. John Wiley, Sussex.

Crawley M.J. 2002b. Chapter 40 Multivariate statistics [Internet]. Added chapter, Statistical Computing: an Introduction to Data Analysis Using S-plus. Available: >http://www.bio.ic.ac.uk/research/mjcraw/statcomp/ welcome.htm<

Denno R.F., Hawthorne D.J., Thorne B.L., Gratton C. 2002. Reduced flight capability in British Virgin Island populations of a wing-dimorphic insect: the role of habitat isolation, persistence, and structure. Ecological Entomology 26: 25-36.

Diamond J.M. 1981. Flightlessness and fear of flying in island species. Nature 293: 507-508

Eldridge M.D.B., Kinnear J.E., Zenger K.R., McKenzie L.M., Spencer P.B.S. 2004. Genetic diversity in remnant mainland and "pristine" island populations of three endemic Australian macropodids (Marsupialia): Macropus eugenii, Lagorchestes hirsutus and Petrogale lateralis. Conservation Genetics 5: 325-338. 
Escobar-Paramo P., Ghosh S., DiRuggiero J. 2005. Evidence for genetic drift in the diversification of a geographically isolated population of the hyperthermophilic archaeon Pyrococcus. Molecular Biology and Evolution 22: 2297-2303.

Ferreira S.A., Vasconcellos-Neto J. 2001. Host plants of the grasshopper Cornops aquaticum (Bruner) (Orthoptera: Acrididae) in the wetland of Poconé, MT, Brazil. Neotropical Entomology 30: 523-533.

Fowler J., Cohen L. 1996. Practical Statistics for Field Biology. Wiley, Chichester.

Fox J. 2002. Linear mixed models. Appendix to An R-and S-Plus companion to applied regression. [Internet] Available: >http://cran.r-project.org/doc/ contrib/Fox-Companion/appendix-mixed-models.pdf<

Franceschini M.C., Capello S., Lhano M., Adis J., De Wysiecki M.L. 2005. Morfometría de los estadios ninfales de Cornops aquaticum Bruner (1906) (Acrididae: Leptysminae) en Argentina. Amazoniana 8: 373-386.

Futuyma D.J. 1986. Evolutionary Biology. Sinauer, Sunderland.

Gerloff C.U., Schmidt-Hempel P. 2005. Inbreeding depression and family variation in a social insect, Bombus terrestris (Hymenoptera: Apidae). Oikos 111: 67-80.

Hill M.P., Oberholzer I.G. 2000. Host specifity of the grasshopper, Cornops aquaticum, a natural enemy of water hyacinth, pp 349-356. In: Spencer N.R. (Ed.). Proceedings of the $\mathrm{X}^{\text {th }}$ International Symposium on Biological Control of Weeds 4-14 July1999. Montana State University, Bozeman,U.S.A.

Hurlbert S.H. 1984. Pseudoreplication and the design of ecological field experiments. Ecological Monographs 54: 187-211.

Lhano M.G., Adis J., Marques M.I., Battirola L.D. 2005. Cornops aquaticum (Orthoptera, Acrididae, Leptisminae): aceitação de plantas alimentares por ninfas vivendo em Eichhornia azurea (Pontederiaceae) no Pantanal Norte, Brasil. Amazoniana 18: 397-404.

Manly B.F.J. 2000. Multivariate Statistical Methods: a Primer. CRC Press/ Chapman \& Hall, Boca Raton.

Oberholzer I.G., Hill M.P. 2001. How safe is the grasshopper Cornops aquaticum for release on water hyacinth in South Africa?, pp. 82-88. In: Julien M.H., Hill M.P., CenterT.D., Jianqing D. (Eds) Biological and Integrated Control of Water Hyacinth, Eichhornia crassipes. ACIAR Proceedings .

Peer K., Taborskyi M. 2005. Outbreeding depression, but no inbreeding depression in haplodiploid ambrosia beetles with regular sibling mating. Evolution 59: 317-323.

Pinheiro J.C., Bates D.M. 2000. Mixed-effects Models in S and S-plus. Springer, New York.

Price P.W. 1997. Insect Ecology. 3rd edition. John Wiley \& Sons, New York.

R Development Core Team 2006. R: A language and environment for statistical computing. The R Project for Statistical Computing, Vienna, Austria. ISBN 3-900051-07-0, URL http://www.R-project.org

Roff D.A. 1994. The evolution of flightlessness: is history important? Evolutionary Ecology 8: 639-657.

Schaal B.A., Leverich W.J. 2005. Conservation genetics: theory and practice. Annals of the Missouri Botanical Garden 92: 1-11.

Silveira-Guido A.S., Perkins B.D. 1975. Biology and host specificity of Cornops aquaticum (Bruner) (Orthoptera: Acrididae), a potential biological-control agent for water-hyacinth. Environmental Entomology 4: 400-404.

Simpson S.J., Despland E., Hagele B.F., Dodgson T. 2001. Gregarious behavior in desert locusts is evoked by touching their back legs. Proceedings National Academy of Sciences United States of America 98: 3895-3897.

Sword G.A., Simpson S.J. 2000. Is there an intraspecific role for densitydependent colour change in the desert locust? Animal Behaviour 59: 861-870.

Uvarov B. 1966. Grasshoppers and Locusts. Vol. 1. Cambridge Univ. Press, Cambridge. 